\title{
Evaluation of Supply Chain Financial Performance from the Perspective of Balance, Strength, and Resiliency: A Case of Korean Enterprises
}

Author(s): Oh Kyoung Kwon, Ha-Neul Han, Hye-Min Chung

Source: Journal of International Logistics and Trade 2018; 16(1):21-31

Published by: Jungseok Research Institute of International Logistics and Trade, Inha University

DOI: https://doi.org/10.24006/jilt.2018.16.1.021

The Journal of International Logistics and Trade is an official journal published by Jungseok Research Institute of International Logistics and Trade, Inha University, Korea. JILT welcomes manuscripts that advance the practice and science of logistics, trade, and other related fields.

Frequency: Quarterly (March, June, September, December)

Stable URL: https://www.ejilt.org

The Jungseok Research Institute of International Logistics and Trade is a specialized academic research institute representing Inha University and the Inha Foundation in Korea. The institute aims to become a representative institute in Northeast Asia in the research of logistics and trade.

Stable URL: https://jrieng.inha.ac.kr

(C) Copyright. Jungseok Research Institute of International Logistics and Trade.

This is an Open-Access article distributed under the terms of the Creative Commons Attribution NonCommercial License (http://creativecommons.org/licenses/by-nc/4.0/) which permits unrestricted noncommercial use, distribution, and reproduction in any medium, provided the original work is properly cited 


\title{
Journal of
}

\section{International Logistics and Trade}

\section{Evaluation of Supply Chain Financial Performance from the Perspective of Balance, Strength, and Resiliency: A Case of Korean Enterprises}

\author{
Oh Kyoung Kwon ${ }^{\mathrm{a}}$, Ha-Neul Han ${ }^{\mathrm{a} *}$, Hye-Min Chung ${ }^{\mathrm{b}}$ \\ a Asia Pacific School of Logistics, Inha University, Incheon, Korea \\ ${ }^{\mathrm{b}}$ Graduate School of Logistics, Inha University, Incheon, Korea
}

\section{ARTICLE INFO \\ Article history: \\ Received 20 November, 2017 \\ Accepted 19 April, 2018 \\ Keywords: \\ Cash to-cash cycle time \\ Supply chain financial \\ performance}

Supply chain management
JOURNAL OF

INTERNATIONAL

LOGISTICS

AND TRADE

\section{Introduction}

Among the various methodologies to evaluate the performance of supply chains composed of the plan-procurementproduction-shipment process, the SCOR model is a highly practical evaluation method in that it comprises four components: Plan, Source, Make, and Deliver. The SCOR model is an integrated performance index of supply chains. However, due to difficulty in collecting performance data, studies have been limited to the application of a single performance index, such as cash-to-cash cycle time (C2C). However, evaluating the performance of supply chains only through $\mathrm{C} 2 \mathrm{C}$ is not desirable because an intentional extension of days of account payables possibly worsens the integrity of the whole supply chain (Cecere and Mayer, 2014b) according to the $\mathrm{C} 2 \mathrm{C}$ measurement system.

Recent studies concerning the Supply Chain Index (SCI) from Supply Chain Insight LCC driven by Cecere and Mayer (2014a) are based on the fact that supply chains are complex non-linear systems, and are becoming increasingly complex. Accordingly, we consider the possibility of disruption to the supply chain as a whole as well as the case that a single performance indicator is used. Consequently, this study includes balance and strength to analyze not only the performance of the time period but also its improvement. Furthermore, $\mathrm{SCI}$ is differentiated from existing performance measurement systems by addressing the stability of supply chain performance, fluctuation, and improvements through the measurement of resiliency (Cecere and Mayer, 2014a).

The main aim of this study is to review SCI concepts and present comparison results with $\mathrm{C} 2 \mathrm{C}$ through a case study of Korean firms in order to examine their potential complementary application. The remainder of this paper is organized as follows: Section 2 details the literature review, and the third section compares $\mathrm{C} 2 \mathrm{C}$ and SCI, as well as provides an explanation of each indicator. In the fourth section, we present the evaluation results of the supply chain financial performance of domestic manufacturing enterprises and wholesale and retail trade enterprises, classified according to the size and type of enterprises. In the last section, we summarize our results and discuss the applicability of this approach.

\footnotetext{
* Asia Pacific School of Logistics, Inha University, 100 Inha-ro, Nam-gu, Incheon, 22212, Korea, Email: hnhan@inha.ac.kr
} 
Table 1. Literature review

\begin{tabular}{|c|c|c|}
\hline Literature & Sample data & Contents \\
\hline $\begin{array}{l}\text { Richard and } \\
\text { Laughlin } \\
\text { (1980) }\end{array}$ & & $\begin{array}{l}\text { - Investigated the idea of C2C as a fundamental tool to measure a firm's } \\
\text { performance as well as a firm's liquidity. } \\
\text { - Studied C2C as the net time interval between a firm's cash expenditure and } \\
\text { eventual recovery of cash receipts from sales. }\end{array}$ \\
\hline $\begin{array}{l}\text { Lyroudi and } \\
\text { Lazaridis } \\
\quad(2000)\end{array}$ & $\begin{array}{l}82 \text { major Greek firms in food } \\
\text { and beverage industries. (1997) }\end{array}$ & $\begin{array}{l}\text { - Investigated the implications of the } \mathrm{C} 2 \mathrm{C} \text { as a liquidity indicator, regarding } \\
\text { profitability, indebtedness, and firm sizes. } \\
\text { - The methodology includes regression and correlation analysis with } t \text {-test of } \\
\text { sample means. } \\
\text { - Found positive relationships between the } \mathrm{C} 2 \mathrm{C} \text { and traditional liquidity } \\
\text { measures, return on assets and net profit margins. }\end{array}$ \\
\hline Kim et al. (2003) & 621 Korean firms (1997-2001) & $\begin{array}{l}\text { - Studied supply chain asset performance with } \mathrm{C} 2 \mathrm{C} \text {, inventory days and asset } \\
\text { turn. } \\
\text { - Found that large firms' performance is better than small firms' performance } \\
\text { and retail industry shows better performance than manufacturing industry } \\
\text { does. }\end{array}$ \\
\hline $\begin{array}{l}\text { Pfohl and Gomm } \\
\qquad(2009)\end{array}$ & & $\begin{array}{l}\text { - Analyzed the role of financial flows in supply chain. } \\
\text { - A mathematical model is developed to explain financing activities of supply } \\
\text { chain and } \mathrm{C} 2 \mathrm{C} \text { is used as the key figure of financial flows. }\end{array}$ \\
\hline $\begin{array}{l}\text { Akgün and } \\
\text { Gürünlü }(2010)\end{array}$ & & $\begin{array}{l}\text { - Investigated a theoretical view of } \mathrm{C} 2 \mathrm{C} \text { and its factors as a tool for evaluation } \\
\text { of supply chain regarding } \mathrm{C} 2 \mathrm{C} \text { as an integral metric. }\end{array}$ \\
\hline $\begin{array}{l}\text { Shin and Soenen } \\
\text { (1998) }\end{array}$ & $\begin{array}{l}58985 \text { American firms } \\
(1975-1994)\end{array}$ & $\begin{array}{l}\text { - Studied the relationship between the firm's net trade cycle and its profitability } \\
\text { by regression and correlation analysis. } \\
\text { - Found a strong negative association between } \mathrm{C} 2 \mathrm{C} \text { and profitability and } \\
\text { liquidity of firms. }\end{array}$ \\
\hline Deloof (2003) & $\begin{array}{l}1009 \text { large Belgian non-financial } \\
\text { firms (1992-1996) }\end{array}$ & $\begin{array}{l}\text { - Investigated the relation between working capital management and } \\
\text { profitability, using regression. } \\
\text { - Variables including C2C is used as measures of working capital management. } \\
\text { - Results suggest that profitability is inversely related to the number of days of } \\
\text { accounts receivable and inventories. }\end{array}$ \\
\hline Eljelly (2004) & $\begin{array}{l}929 \text { stock companies in Saudi } \\
\text { Arabia (1996-2000) }\end{array}$ & $\begin{array}{l}\text { - The study examined the relation between profitability and liquidity by } \\
\text { regression model. } \\
\text { - Found that } \mathrm{C} 2 \mathrm{C} \text { is important factor to measure liquidity. }\end{array}$ \\
\hline $\begin{array}{l}\text { Garcia-Teruel } \\
\text { and Martinez- } \\
\text { Solano (2007) }\end{array}$ & $\begin{array}{l}\text { 8872 Spanish SMEs } \\
(1996-2002)\end{array}$ & $\begin{array}{l}\text { - Measured effects of working capital on firm profitability. } \\
\text { - Results demonstrated that value could be created by reducing the number of } \\
\text { days of account variables. } \\
\text { - Found reducing number of days of inventory and account variables as well as } \\
\text { C2C is significantly related to profitability. }\end{array}$ \\
\hline $\begin{array}{l}\text { Anser and Malik } \\
\qquad(2013)\end{array}$ & $\begin{array}{l}155 \text { manufacturing companies o } \\
\text { Pakistan. (2007-2011) }\end{array}$ & $\begin{array}{l}\text { Analyzed how the changes of } \mathrm{C} 2 \mathrm{C} \text { affects profitability in the sample with } \\
\text { regression model. } \\
\text { - The result showed that shorter } \mathrm{C} 2 \mathrm{C} \text { leads to increased profitability. }\end{array}$ \\
\hline $\begin{array}{c}\text { Ebben and } \\
\text { Johnson (2011) }\end{array}$ & $\begin{array}{l}879 \text { small U.S. manufacturing } \\
\text { firms and } 833 \text { small U.S. retail } \\
\text { firms }(2002-2004)\end{array}$ & $\begin{array}{l}\text { - Investigated the relationship between } \mathrm{C} 2 \mathrm{C} \text { and levels of liquidity, invested } \\
\text { capital, and performance. } \\
\text { - Provided support that } \mathrm{C} 2 \mathrm{C} \text { is an important measure for a firm's management. }\end{array}$ \\
\hline $\begin{array}{l}\text { Abuzayed } \\
(2012)\end{array}$ & $\begin{array}{l}52 \text { firms listed in a small and } \\
\text { emerging market. (2000-2008) }\end{array}$ & $\begin{array}{l}\text { - Examined the effect of working capital management measured by } \mathrm{C} 2 \mathrm{C} \text { on } \\
\text { firm's performance. } \\
\text { - The sample was analyzed by correlation and regression model. } \\
\text { - Found firm's profitability is positively related to } \mathrm{C} 2 \mathrm{C} \text {. }\end{array}$ \\
\hline $\begin{array}{l}\text { Yazdanfar and } \\
\text { Öhman (2014) }\end{array}$ & $\begin{array}{l}\text { 13,797 Swedish SMEs } \\
(2008-2011)\end{array}$ & $\begin{array}{l}\text { - The study used a seemingly unrelated regression (SUR) model to find } \\
\text { empirical evidence that } \mathrm{C} 2 \mathrm{C} \text { affects profitability. } \\
\text { - The result showed that longer } \mathrm{C} 2 \mathrm{C} \text { are less profitable and variance from the } \\
\text { optimal } \mathrm{C} 2 \mathrm{C} \text { level decreases firm's profitability. }\end{array}$ \\
\hline Gill et al. (2010) & $\begin{array}{l}88 \text { American manufacturing } \\
\text { firms } \\
(2005-2007)\end{array}$ & $\begin{array}{l}\text { - Investigated the relationship between working capital management and the } \\
\text { firm's profitability using regression model. } \\
\text { - Found positive relationship between } \mathrm{C} 2 \mathrm{C} \text { and profitability. }\end{array}$ \\
\hline $\begin{array}{l}\text { Muscettola } \\
\text { (2014) }\end{array}$ & $\begin{array}{l}\text { 4,226 Italian manufacturing } \\
\text { SMEs }(2007-2010)\end{array}$ & $\begin{array}{l}\text { - Studied how C2C affects a firm's profitability with cluster analysis and } \\
\text { regression. } \\
\text { - Results showed no significant association between C2C and profitability. }\end{array}$ \\
\hline
\end{tabular}

\section{Literature review}


Predominantly, previous research concerning firm performance has employed $\mathrm{C} 2 \mathrm{C}$ for financial analysis. Richard and Laughlin (1980) clarified the idea of C2C as a fundamental tool for measuring a firm's performance as well as a firm's liquidity, defining $\mathrm{C} 2 \mathrm{C}$ as the net time interval between a firm's cash expenditure and eventual recovery of cash receipts from sales. Other studies have also regarded $\mathrm{C} 2 \mathrm{C}$ as an effective indicator for evaluating firm performance (Lyroudi and Lazaridis, 2000; Kim et al. 2003; Pfohl and Gomm 2009). In addition, Akgün and Gürünlü (2010) introduced C2C as a criterion to evaluate the performance of supply chain as a whole.

Studies regarding C2C and firm profitability and performance suggest an inverse relationship (Shin and Soenen 1998; Deloof 2003; Eljelly 2004; Pacachi; Garcia-Teruel and Martinez-Solano 2007; Anser and Malik 2013). Some studies have used a regression model as the main method to analyze the relationship between C2C and performance (Deloof 2003; Eljelly 2004; Padachi 2006; Ebben and Johnson 2011; Abuzayed 2012; Yazdanfar and Öhman 2014). Yazdanfar and Öhman (2014) emphasized that a firm's C2C is not necessarily required to be short in order to realize great profitability, identifying that too short or too long $\mathrm{C} 2 \mathrm{C}$ reduces a firm's performance. However, several studies have found the opposite results, including a positive relationship between long $\mathrm{C} 2 \mathrm{C}$ and firm performance, as well as no strong correlation between C2C and firm performance (Gill et al. 2010; Abuzayed 2012; Muscettola 2014). In particularly, Abuzyed (2012) argued that more profitable firms might have less motivation of working capital management.

As indicated above, many prior studies utilize $\mathrm{C} 2 \mathrm{C}$ for a firm performance evaluation methodology, and results have varied. In this paper, we will analyze Korean manufacturing and wholesale and retail firm performance employing $\mathrm{C} 2 \mathrm{C}$ as well as SCI.

\section{Review of supply chain financial performance measures: C2C and SCI}

\section{$3.1 C 2 C$}

The cash to cash cycle time is the length of time that it takes for an enterprise to purchase raw materials, complete the manufacturing process, and convert these products into income. $\mathrm{C} 2 \mathrm{C}$ is the main index to measure asset performance, as one of the 12 performance indices from the supply chain operations reference model. Due to its easy data acquisition, $\mathrm{C} 2 \mathrm{C}$ has been applied to various domestic and foreign studies.

A detailed calculation procedure for $\mathrm{C} 2 \mathrm{C}$ is as follows: We subtract days of payables from the sum of days of inventory and days of receivables. If $\mathrm{C} 2 \mathrm{C}$ is relatively long, this implies that the amount of time spent in converting inventory and accounts receivable into cash is relatively long. It causes increases in additional cash infusion costs as a result of interest payments. Eventually, this worsens cost issues and competitiveness of enterprises, and it is necessary for enterprises to improve their $\mathrm{C} 2 \mathrm{C}$ through rapid delivery of goods to customers, faster collection of payment, efficient inventory management, and rapid raw materials acquisition (Kim et al., 2003).

$$
\begin{aligned}
& \text { C2C }=(\text { Days of Inventory }+ \text { Days of Receivables })-\text { Days of Payables } \\
& \text { Days of Inventory }=\text { Inventory } \div(\text { Cost of Sales } \div 365(\text { days })) \\
& \text { Days of Receivables }=365(\text { days }) \div \text { Receivable Turnover } \\
& \text { Days of Payables }=365(\text { days }) \div \text { Payable Turnover }
\end{aligned}
$$

\section{$3.2 S C I$}

As mentioned prior, relying only on a particular indicator is likely to cause confusion in the overall supply chain management. Accordingly, Supply Chain Insight LCC considers a more complex financial performance indicator, and divides categories into growth, profitability, cycle, and complexity factor, and extracts financial factors representing performance for each category. In later studies of Cecere and Mayer (e.g.,2014a), balance, strength, and resiliency were selected. as main indicators of SCI. Balance is based on the analysis of revenue growth and return on invested capital for a specific enterprise. Strength is based on the analysis of operating margin and inventory turns. Resiliency is based on a scatter plot of strength, indicating the ability of a supply chain to maintain consistency in response to environmental changes and improvements. Cecere and Mayer (2014a) set the contribution of balance, strength, and resiliency as $30 \%$ each toward the final score, and the remaining $10 \%$ derives from a peer vote contributed by a professional panel. Among these four components, three quantitative components are measured by the following methodology

First, balance focuses on maintaining an adequate inventory level. Reduced inventory levels weaken customer service levels, and excess inventory leads to higher costs. Balance is comprised of revenue growth and return on invested capital. High balance scores represent a well-balanced performance of the supply chain.

$$
\text { Balance }=\frac{1}{n-1}\left(\frac{R E V_{n}-R E V_{1}}{R E V_{1}}+\frac{R O I C_{n}-R O I C_{1}}{R O I C_{1}}\right)
$$


where $\operatorname{Rev}_{i}$ : revenue growth of $i$ th period, $\operatorname{ROIC}_{i}$ : return on investment capital of $i$ th period, and $n$ : period used in research, $2010(i=1) \sim 2016(i=7)$.

Second, the strength component analyzes inventory turns and operating margins of supply chains. A higher score signifies higher performance of supply chains from the perspective of strength.

$$
\text { Strength }=\frac{1}{n-1}\left(\frac{O M_{n}-O M_{1}}{O M_{1}}+\frac{I T_{n}-I T_{1}}{I T_{1}}\right)
$$

where $O M_{i}$ : operating margin of $i$ th period and $I T_{i}$ : inventory turns of $i$ th period.

Third, resiliency is based on the intersection of operating margins and inventory turns. The lower value indicates a high ability to sustain consistency in response to environmental shifts and other changes.

$$
\text { Resilency }=\frac{1}{m} \sum_{i} \sum_{j>i} d_{i j}
$$

where $m$ : total number of pairs and $d_{i j}$ : Euclidean distance between a pair of points $i$ and $j(j>i)$.

\begin{tabular}{c|c|c|c|c|c|c|}
\multicolumn{7}{c}{ Operating margins $(x)$} \\
\cline { 2 - 7 } & $j \backslash i$ & 1 & 2 & $\ldots$ & 6 & 7 \\
\cline { 2 - 7 } & 1 & 0 & 0 & $\ldots$ & 0 & 0 \\
\cline { 2 - 7 } $\begin{array}{c}\text { Inventory } \\
\text { turns }(y)\end{array}$ & 2 & $d_{12}$ & 0 & $\ldots$ & 0 & 0 \\
\cline { 2 - 7 } & 3 & $d_{13}$ & $d_{23}$ & $\ldots$ & 0 & 0 \\
\cline { 2 - 7 } & $\ldots$ & $\ldots$ & $\ldots$ & $\ldots$ & 0 & 0 \\
\hline & 7 & $d_{17}$ & $d_{27}$ & $\ldots$ & $d_{67}$ & 0 \\
\hline
\end{tabular}

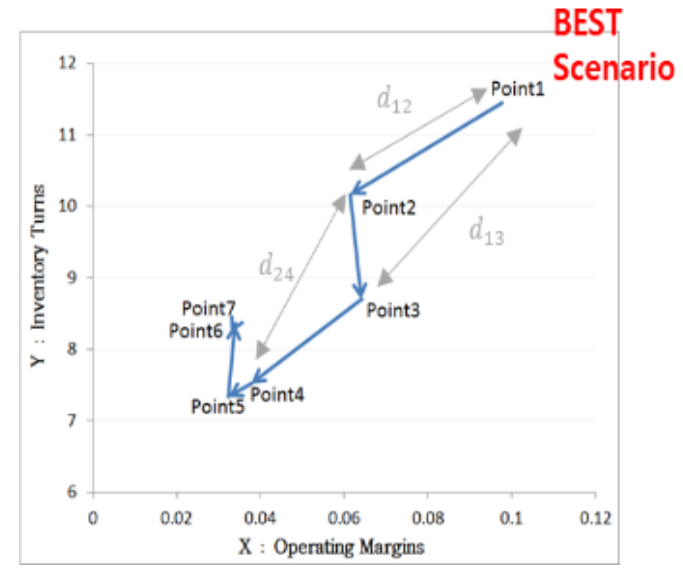

Figure 1. Measurement process of resiliency and its visualized result

As shown in Figure 1, Euclidean distances between a pair of points $i$ and $j$ on the rectangular coordinates of operating margin and inventory turn are measured, and the mean distance of all possible pairs of points at the intersections denotes resiliency. When the graph features its direction toward quadrant 4 , this represents an ideal case in that performance is improving every year.

\section{Evaluation of supply chain financial performance: Case of Korean companies}

\subsection{Source of measurement and data collection}

To compare SCI and C2C as supply chain performance indicators, balance panel data was collected from the annual report of 2,239 enterprises (1,867 from manufacturing industry, 372 from wholesale and retail trade industry) from 2012 2016 (The analysis period of this study is from 2012 to 2016 but measuring SCI requires data from 2011 as it includes improvements over years.) and whose closing account was settled in December. Data was extracted from the KIS-VALUE (NICE Information Service) and measurement results are as follows:

\subsection{Measurement result classified by industry}

As shown in Table 2, the $\mathrm{C} 2 \mathrm{C}$ of wholesale and retail trade was shorter than the manufacturing industry during the analysis period. Both industries tended to have longer $\mathrm{C} 2 \mathrm{C}$ over the last five years, which we assume is the result of stagnation in the domestic economy due to the recent economic downturn. Especially, the days of inventory of the manufacturing industry remained stable, as it slightly changed during the study period from 53.8 days (2012) to 54.2 days (2016) whereas that of wholesale and retail trade greatly increased from 40.4 days to 47.8 days. This is the main factor contributing to the increasing $\mathrm{C} 2 \mathrm{C}$. 
Table 2. Measurement result of $\mathrm{C} 2 \mathrm{C}$ according to the types of enterprise

\begin{tabular}{cccccccc}
\hline & & $` 12$ & $` 13$ & $` 14$ & $' 15$ & 16 & $n$ \\
\hline \multirow{4}{*}{ Manufacturing } & C2C & 86.2 & 88.1 & 90.5 & 91.6 & 92.2 & 1,867 \\
& Days of inventory & 53.8 & 54.1 & 55.4 & 55.3 & 54.2 & 1,867 \\
& Days of receivables & 65.5 & 65.2 & 66.5 & 67.0 & 69.5 & 1,867 \\
& Days of payables & 33.2 & 31.2 & 31.4 & 30.7 & 31.5 & 1,867 \\
\hline \multirow{3}{*}{ Wholesale and } & C2C & 58.4 & 56.2 & 62.4 & 64.7 & 70.0 & 372 \\
retail trade & Days of inventory & 40.4 & 39.4 & 42.0 & 45.4 & 47.8 & 372 \\
& Days of receivables & 48.3 & 46.5 & 49.1 & 47.7 & 50.9 & 372 \\
& Days of payables & 30.4 & 29.6 & 28.7 & 28.4 & 28.6 & 372 \\
\hline
\end{tabular}

* Based on median value

As Cerere and Meyer (2014a) have mentioned, balance is the sum of revenue growth and return on invested capital, strength is the sum of inventory turns and operating margins, and resiliency is based on the pattern of the intersection of operating margin and inventory turns. They also detailed that measuring the current performance, how it is improved from previous years, and the stability of its improvement is an important part of SCI measurement.

In this respect, all values of balance and strength of both industries in given periods are negative (-), showing low financial performance level, as shown in Table 3. However, regarding improvement, values are positive, which indicates both industries are improving. In particular, the manufacturing industry shows higher improvement compared with the wholesale and retail trade industry. Resiliency scores of 0.202 for manufacturing and 0.262 for wholesale and retail trade industry were found, which shows that the manufacturing industry is performing better than the wholesale and retail trade industry.

Table 3. The measurement result of balance, strength, and resiliency according to the industry

\begin{tabular}{|c|c|c|c|c|c|c|c|}
\hline & & $` 12$ & $` 13$ & $` 14$ & $` 15$ & $` 16$ & $\mathrm{n}$ \\
\hline \multirow{3}{*}{ manufacturing } & Balance & -0.641 & -0.423 & -0.316 & -0.272 & -0.216 & 1,867 \\
\hline & Strength & -0.193 & -0.134 & -0.120 & -0.094 & -0.059 & 1,867 \\
\hline & Resiliency & & & 0.202 & & & 1,867 \\
\hline \multirow{3}{*}{$\begin{array}{l}\text { wholesale and } \\
\text { retail trade }\end{array}$} & Balance & -0.616 & -0.433 & -0.294 & -0.344 & -0.240 & 372 \\
\hline & Strength & -0.117 & -0.113 & -0.108 & -0.096 & -0.070 & 372 \\
\hline & Resiliency & & & 0.262 & & & 372 \\
\hline
\end{tabular}

* Based on median value

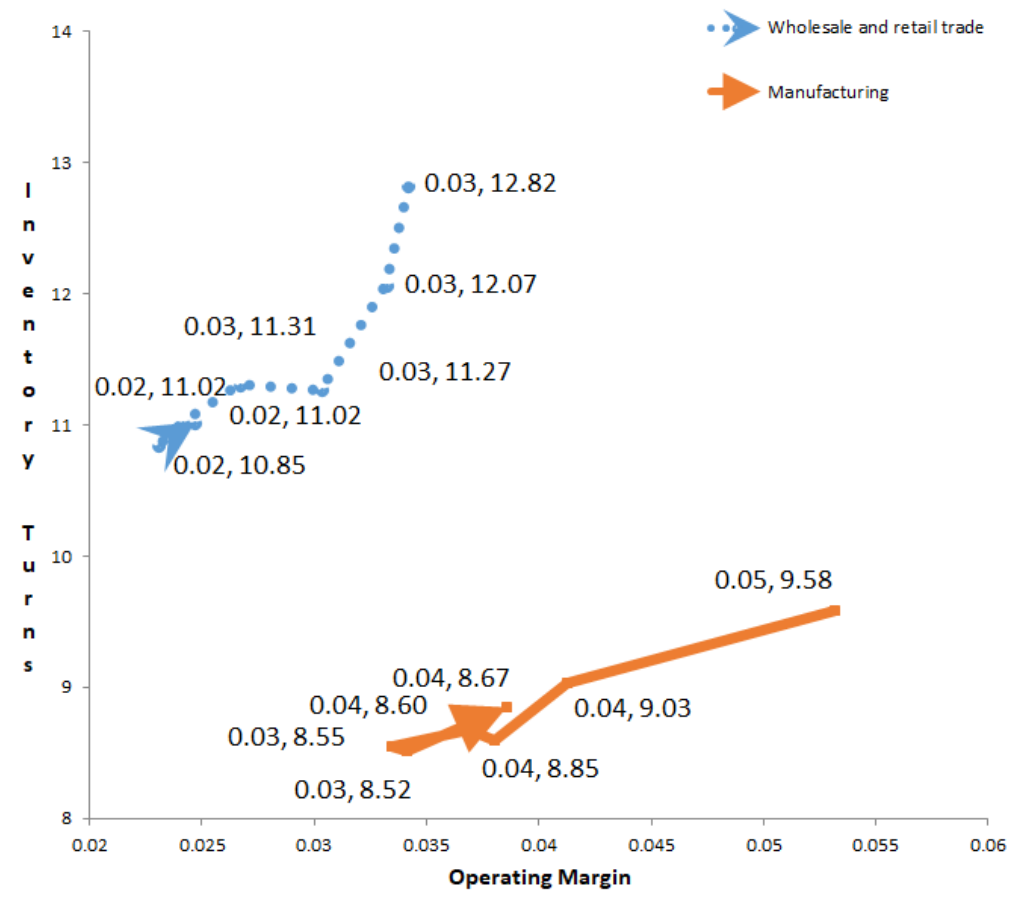

Figure 2. The resiliency changes according to industry 
However, when visualizing the resiliency changes according to the industry as shown in Figure 2, both are not trending toward quadrant 4 . This implies that the manufacturing industry is clearly maintaining its supply chain with the tighter consistency of operating margins and inventory turns than the wholesale and retail trade industry, but both should intensify efforts for improving performance.

\subsection{Measurement result classified by industry and size of enterprises.}

As shown in Table 4, the $\mathrm{C} 2 \mathrm{C}$ of small- and medium-sized enterprises (SMEs) in the manufacturing industry has increased over the last 5 years. The $\mathrm{C} 2 \mathrm{C}$ of large manufacturing enterprises has changed from 85.1 days (2012) to 87.3 days (2016) while that of SMEs has increased from 87.1 days to 97.9 days during this period. Especially in the case of SMEs, the $\mathrm{C} 2 \mathrm{C}$ gap has enlarged over time. Thus, it is necessary to improve the management strategy of SMEs for continuous improvement.

Also, in the case of the wholesale and retail trade industry, $\mathrm{C} 2 \mathrm{C}$ has increased throughout the study period. We assume $\mathrm{C} 2 \mathrm{C}$ has been negatively affected by stagnation in the domestic economy and the recent downturn in consumption. The C2C of large wholesale and retail trade enterprises have increased from 42.2 days (2012) to 57.2 (2016) and that of SMEs has changed from 75.2 days to 84.5 during this time.

The main factor of worsening $\mathrm{C} 2 \mathrm{C}$ performance is the increase in days of inventory and days of receivables. While days of inventory for large enterprises has increased from 35.5 days (2012) to 42.8 days (2016), that of SMEs has changed from 47.1 days to 47.6 days over this period, which shows a relatively larger increase for large enterprises. Days of receivables of large enterprises have changed from 35.2 days (2012) to 42.3 days (2016) while that of SMEs has changed from 60.1 days to 66.4 days. This suggests that in the wholesale and retail trade industry, the increase in days of receivables is a key factor negatively affecting the $\mathrm{C} 2 \mathrm{C}$.

Table 4. The measurement result of $\mathrm{C} 2 \mathrm{C}$ classified by industry and size of enterprises

(unit : day)

\begin{tabular}{|c|c|c|c|c|c|c|c|c|}
\hline & & Size of enterprise & 12 & 13 & $` 14$ & $` 15$ & $' 16$ & $n$ \\
\hline \multirow{8}{*}{ Manufacturing } & \multirow{2}{*}{$\mathrm{C} 2 \mathrm{C}$} & Large enterprise & 85.1 & 85.2 & 87.6 & 87.7 & 87.3 & 627 \\
\hline & & SME & 87.1 & 89.5 & 92.7 & 93.7 & 97.9 & 1,240 \\
\hline & \multirow{2}{*}{ Days of inventory } & Large enterprise & 52.4 & 51.4 & 53.3 & 51.1 & 51.9 & 627 \\
\hline & & SME & 55.6 & 55.7 & 57.4 & 57.6 & 59.1 & 1,240 \\
\hline & \multirow{2}{*}{$\begin{array}{l}\text { Days of } \\
\text { receivables }\end{array}$} & Large enterprise & 64.1 & 62.9 & 63.4 & 65.2 & 65.1 & 627 \\
\hline & & SME & 66.4 & 67.0 & 67.6 & 67.7 & 71.3 & 1,240 \\
\hline & \multirow{2}{*}{ Days of payables } & Large enterprise & 31.4 & 29.2 & 29.1 & 28.6 & 29.7 & 627 \\
\hline & & SME & 34.8 & 33.1 & 32.3 & 31.6 & 32.5 & 1,240 \\
\hline \multirow{8}{*}{$\begin{array}{l}\text { Wholesale and } \\
\text { retail trade }\end{array}$} & \multirow{2}{*}{$\mathrm{C} 2 \mathrm{C}$} & Large enterprise & 42.2 & 43.3 & 49.4 & 46.8 & 57.4 & 121 \\
\hline & & SME & 75.2 & 77.9 & 85.8 & 84.0 & 84.5 & 251 \\
\hline & \multirow{2}{*}{ Days of inventory } & Large enterprise & 35.5 & 35.3 & 38.4 & 35.0 & 42.8 & 121 \\
\hline & & SME & 47.1 & 47.1 & 52.8 & 48.0 & 47.6 & 251 \\
\hline & \multirow{2}{*}{$\begin{array}{l}\text { Days of } \\
\text { receivables }\end{array}$} & Large enterprise & 35.2 & 36.7 & 37.4 & 39.0 & 42.3 & 121 \\
\hline & & SME & 60.1 & 60.2 & 62.5 & 64.6 & 66.4 & 251 \\
\hline & \multirow{2}{*}{ Days of payables } & Large enterprise & 28.5 & 28.8 & 26.4 & 27.2 & 27.7 & 121 \\
\hline & & SME & 32.0 & 29.5 & 29.4 & 28.6 & 29.5 & 251 \\
\hline
\end{tabular}

* Based on median value

Table 5 shows the SCI analysis results according to the size of enterprise. Regardless of the size of firms, both industries have low performance regarding balance, showing negative values. However, enterprises in both industries are improving their performance. Particularly in the manufacturing industry, large enterprises are performing better, and in the wholesale and retail trade industry, the SMEs are relatively better in performance. Regarding the strength indicator, large enterprises in the manufacturing industry are the only group featuring positive values, and thus, showing improvement. The SMEs are also improving but still contain negative values in both industries.

We additionally conducted $t$-test to check whether the results based on $\mathrm{C} 2 \mathrm{C}$ were statistically significant. Two groups were determined as firm size (a group of large enterprises and a group of SMEs) and the $t$-value is -4.418 showing it is statistically significant at the $1 \%$ significance level. Between large enterprises of both industries, it is also statistically significant at the level of $1 \%$ as the $t$-value is 4.3461 . Thus, we have sufficient support that large enterprises have shorter C2C compared with SMEs, and among large enterprises, firms in the wholesale and retail industry have shorter $\mathrm{C} 2 \mathrm{C}$ than firms in the manufacturing industry. Regarding resiliency, large enterprises $(0.221)$ scored better than SMEs $(0.251)$ in the manufacturing industry, and SMEs (0.429) performed better than large enterprises (0.596) in the wholesale and retail 
trade industry. Greater resiliency means better financial consistency of maintaining supply chain in an unstable environment. As evident from the change in resiliency shown in Figure 3 and Figure 4, the manufacturing industry is more stable than the wholesale and retail trade industry. In addition, the graph of the resiliency of large manufacturing enterprises is approaching quadrant 4 , which indicates financial improvement of the supply chain.

Table 5. The measurement result of SCI classified by industry and size of enterprises

\begin{tabular}{|c|c|c|c|c|c|c|c|c|}
\hline & & Size of enterprise & $` 12$ & $` 13$ & $` 14$ & $` 15$ & $` 16$ & $n$ \\
\hline \multirow{6}{*}{ Manufacturing } & \multirow{2}{*}{ Balance } & Large enterprise & -0.629 & -0.436 & -0.362 & -0.272 & -0.238 & 627 \\
\hline & & SME & -0.571 & -0.425 & -0.335 & -0.278 & -0.237 & 1,240 \\
\hline & \multirow{2}{*}{ Strength } & Large enterprise & 1.228 & 1.393 & 1.469 & 1.573 & 1.615 & 627 \\
\hline & & SME & -0.177 & -0.130 & -0.119 & -0.091 & -0.068 & 1,240 \\
\hline & \multirow{2}{*}{ Resiliency } & Large enterprise & & 0.221 & & & 627 & \\
\hline & & SME & & 0.251 & & & 1,240 & \\
\hline \multirow{6}{*}{$\begin{array}{l}\text { Wholesale and } \\
\text { retail trade }\end{array}$} & \multirow{2}{*}{ Balance } & Large enterprise & -0.479 & -0.368 & -0.293 & -0.368 & -0.152 & 121 \\
\hline & & SME & -0.759 & -0.236 & -0.418 & -0.316 & -0.228 & 251 \\
\hline & \multirow{2}{*}{ Strength } & Large enterprise & -0.209 & -0.171 & -0.118 & -0.114 & -0.101 & 121 \\
\hline & & SME & -0.146 & -0.131 & -0.101 & -0.091 & -0.056 & 251 \\
\hline & \multirow{2}{*}{ Resiliency } & Large enterprise & & 0.596 & & & 121 & \\
\hline & & SME & & 0.429 & & & 251 & \\
\hline
\end{tabular}

* Based on the median value

Figure 3. Changing tendency of resiliency of manufacturing industry

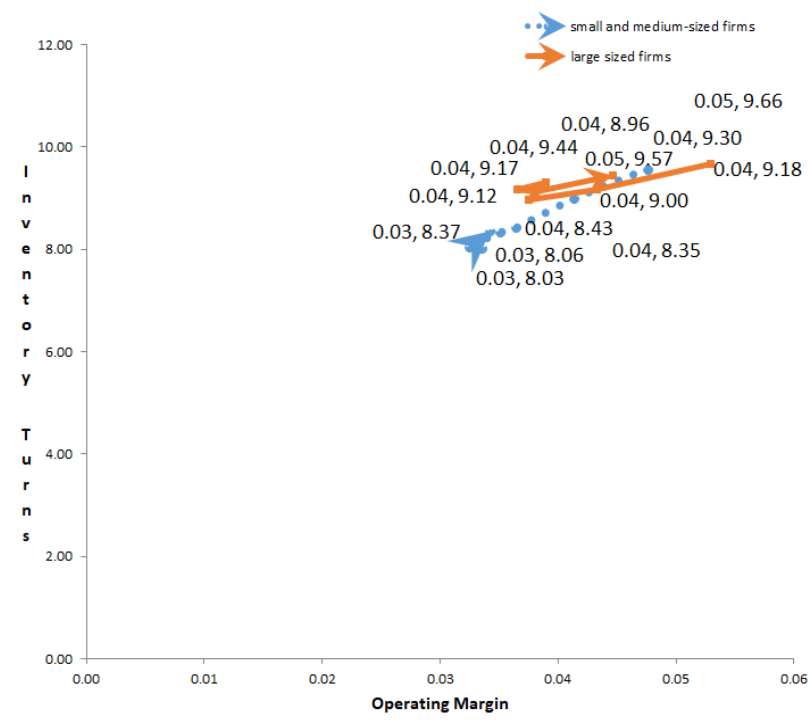

Figure 4. Changing tendency of resiliency of wholesale and retail trade industry

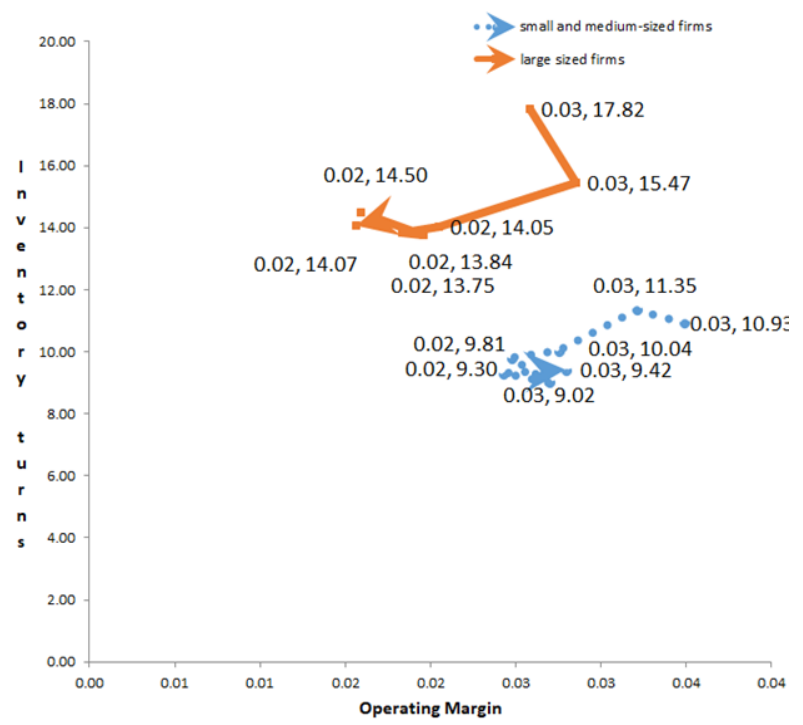

\subsection{Measurement result classified by industry division}

$\mathrm{C} 2 \mathrm{C}$ performance of the manufacturing industry and the wholesale and retail trade industry was classified as follows: $\mathrm{C} 2 \mathrm{C}$ of manufacture of motor vehicles, trailers, and semitrailers, a representative type of business in Korea, is the shortest within the manufacturing industry, with 36.7 days (2012) and 44.2 days (2016). In addition, industries related to consumer goods such as textile and apparel, (manufacture of textiles, except apparel: 173 days (2012) and 209.1 days (2016), manufacture of wearing apparel, clothing accessories and fur articles 165.4 days (2012), 170.1 days (2016)) and bioindustry (manufacture of pharmaceuticals, medicinal chemical and botanical products 210.0 days (2012) and 201.4 days (2016)) have relatively slow C2C, indicating that these industries feature low financial performance. Regarding the wholesale and retail trade industry, the $\mathrm{C} 2 \mathrm{C}$ of the sale of motor vehicles and parts (15.3 days (2012) and 4.5 days (2016)) is the fastest, and that of wholesale trade on own account or on a fee or contract basis (73.0 days (2012), 89.6 days (2016)) is the slowest.

The measurement results of balance, strength, resiliency are shown in Table 7. First, the balance score of the manufacturing industries, excluding manufacture of other non-metallic mineral products and manufacture of pharmaceuticals, medicinal chemical and botanical products, shows negative values, implying low financial performance. Concerning improvement, manufacture of other non-metallic mineral products as well as manufacture of pharmaceuticals, 
medicinal chemical and botanical products showed the highest improvement. This is considered a highly positive result since their performance level is high and improving at the same time. In addition, in the wholesale and retail trade industry, sale of motor vehicles and parts as well as wholesale trade on own account or on a fee or contract basis showed high performance improvement. Second, positive strength scores are shown in manufacture of furniture, manufacture of beverages, manufacture of other non-metallic mineral products, manufacture of food products, and manufacture of wood and of products of wood and cork, excluding furniture. These sectors featured positive strength scores and also have high performance improvement. Among the wholesale and retail trade industry, no sector featured a positive score, implying low performance level in general, but improving. Lastly, high scores of resiliency were found in manufacture of pharmaceuticals, medicinal chemical and botanical products, manufacture of electronic components, computer; visual, sounding and communication equipment, as well as manufacture of medical, precision and optical instruments, watches and clocks manufacturing. Conversely, printing and reproduction of recorded media and manufacture of beverages scored low in resiliency in the manufacturing industry. In wholesale and retail trade industry, wholesale trade on own account or on a fee or contract basis has a strong resiliency score, which implies a high financial consistency in its supply chain. However, sale of motor vehicles and parts showed relative low performance regarding the resiliency result.

Table 6. The measurement result of $\mathrm{C} 2 \mathrm{C}$ classified by standardized division

(unit : day)

\begin{tabular}{|c|c|c|c|c|c|c|c|}
\hline & & `12 & 13 & 14 & $` 15$ & 16 & $n$ \\
\hline \multirow{24}{*}{ Manufacturing } & - Manufacture of motor vehicles, trailers and semitrailers & 36.7 & 40.7 & 43.2 & 47.3 & 44.2 & 210 \\
\hline & - Printing and reproduction of recorded media & 46.2 & 40.7 & 44.0 & 54.8 & 54.9 & 18 \\
\hline & - Manufacture of furniture & 78.2 & 83.7 & 76.6 & 58.7 & 65.3 & 15 \\
\hline & - Manufacture of other transport equipment & 95.5 & 93.2 & 79.5 & 82.1 & 84.3 & 47 \\
\hline & - Manufacture of beverages & 102.6 & 101.3 & 97.1 & 77.4 & 81.7 & 14 \\
\hline & - Manufacture of other non-metallic mineral products & 96.7 & 99.5 & 101.3 & 87.4 & 86.7 & 75 \\
\hline & - Manufacture of rubber and plastics products & 68.4 & 70.9 & 78.7 & 73.3 & 75.4 & 110 \\
\hline & - Manufacture of food products & 70.0 & 72.7 & 69.8 & 73.0 & 66.2 & 38 \\
\hline & - Manufacture of pulp, paper and paper products & 76.7 & 78.4 & 73.0 & 77.1 & 77.9 & 55 \\
\hline & - Manufacture of fabricated metal products, except machinery and furniture & 85.5 & 84.0 & 85.1 & 97.1 & 95.4 & 106 \\
\hline & - Manufacture of electrical equipment & 80.1 & 76.0 & 83.9 & 79.6 & 82.5 & 96 \\
\hline & $\begin{array}{l}\text { - Manufacture of electronic components, computer; visual, sounding and } \\
\text { communication equipment }\end{array}$ & 81.4 & 83.8 & 88.2 & 83.8 & 88.3 & 247 \\
\hline & $\begin{array}{l}\text { - Manufacture of chemicals and chemical products; except pharmaceuticals } \\
\text { and medicinal chemicals }\end{array}$ & 98.8 & 100.5 & 106.2 & 105.7 & 101.3 & 197 \\
\hline & - Manufacture of other machinery and equipment & 101.0 & 105.4 & 104.8 & 102.1 & 109.2 & 207 \\
\hline & - Manufacture of coke, briquettes and refined petroleum products & 88.8 & 88.6 & 88.5 & 92.7 & 95.5 & 8 \\
\hline & - Manufacture of basic metals & 110.4 & 115.5 & 121.6 & 104.9 & 108.0 & 177 \\
\hline & - Manufacture of wood and of products of wood and cork; except furniture & 144.6 & 135.0 & 135.2 & 118.9 & 109.9 & 3 \\
\hline & - Manufacture of leather, luggage & 92.9 & 102.4 & 97.5 & 109.3 & 142.7 & 11 \\
\hline & - Manufacture of textiles, except apparel & 173.0 & 162.4 & 172.7 & 189.3 & 209.1 & 12 \\
\hline & - Other manufacturing & 141.6 & 126.1 & 139.4 & 143.2 & 146.8 & 14 \\
\hline & $\begin{array}{l}\text { - Manufacture of medical, precision and optical instruments, watches and } \\
\text { clocks }\end{array}$ & 129.2 & 128.9 & 131.4 & 141.5 & 158.2 & 54 \\
\hline & - Manufacture of apparel, clothing accessories and fur articles & 165.4 & 211.7 & 188.1 & 178.3 & 170.1 & 60 \\
\hline & - Manufacture of tobacco products & 401.0 & 423.4 & 366.6 & 405.1 & 414.6 & 2 \\
\hline & $\begin{array}{l}\text { - Manufacture of pharmaceuticals, medicinal chemical and botanical } \\
\text { products }\end{array}$ & 210.0 & 220.4 & 219.6 & 212.7 & 201.4 & 91 \\
\hline \multirow{3}{*}{$\begin{array}{l}\text { Wholesale and } \\
\text { Retail trade }\end{array}$} & - Retail trade, except motor vehicles and motorcycles & 26.2 & 32.7 & 31.3 & 25.7 & 29.7 & 47 \\
\hline & - Sale of motor vehicles and parts & 15.3 & 30.4 & 12.2 & 4.9 & 4.5 & 15 \\
\hline & - Wholesale trade on own account or on a fee or contract basis & 73.0 & 78.0 & 82.2 & 92.9 & 89.6 & 310 \\
\hline
\end{tabular}

* Based on the median value

Figure 5 shows the resiliency graph of manufacture of pharmaceuticals, medicinal chemical and botanical product manufacturing and printing and reproduction of recorded media, which represent the highest and lowest performance of resiliency in the manufacturing industry. In Figure 6, the resiliency graph of wholesale trade on own account or on a fee or contract basis and sale of motor vehicles and parts are shown in order to compare the highest and lowest performance of resiliency in the wholesale trade industry. As shown in Figures 5 and 6, sectors with low resiliency performance experience relatively large changes during the analysis period and the improvement direction is also irregular. 
Table 7. The measurement result of SCI classified by standardized division: Improvement over the last 5 years (' $12 \sim$ '16)

\begin{tabular}{|c|c|c|c|c|c|c|c|}
\hline & & \multicolumn{2}{|c|}{ Balance } & \multicolumn{2}{|c|}{ Strength } & \multirow{2}{*}{ Resiliency } & \multirow[b]{2}{*}{$n$} \\
\hline & & 16 & Imp. & '16 & Imp. & & \\
\hline \multirow{24}{*}{ Manufacturing } & $\begin{array}{l}\text { - Manufacture of motor vehicles, trailers and } \\
\text { semitrailers }\end{array}$ & -0.217 & $51 \%$ & -0.053 & $55 \%$ & 0.599 & 210 \\
\hline & - Printing and reproduction of recorded media & -0.058 & $93 \%$ & -0.059 & $-207 \%$ & 6.602 & 18 \\
\hline & - Manufacture of furniture & -0.174 & $79 \%$ & 0.030 & $116 \%$ & 0.546 & 15 \\
\hline & - Manufacture of other transport equipment & -0.195 & $50 \%$ & -0.153 & $53 \%$ & 0.777 & 47 \\
\hline & - Manufacture of beverages & -0.261 & $65 \%$ & 0.101 & $236 \%$ & 1.162 & 14 \\
\hline & - Manufacture of other non-metallic mineral products & 0.184 & $206 \%$ & 0.073 & $168 \%$ & 0.887 & 75 \\
\hline & - Manufacture of rubber and plastics products & -0.200 & $45 \%$ & -0.019 & $114 \%$ & 0.368 & 110 \\
\hline & - Manufacture of food products & -0.532 & $61 \%$ & 0.036 & $115 \%$ & 0.413 & 38 \\
\hline & - Manufacture of pulp, paper and paper products & -0.217 & $39 \%$ & -0.102 & $27 \%$ & 0.782 & 55 \\
\hline & $\begin{array}{l}\text { - Manufacture of fabricated metal products, except } \\
\text { machinery and furniture }\end{array}$ & -0.310 & $33 \%$ & -0.022 & $85 \%$ & 0.331 & 106 \\
\hline & - Manufacture of electrical equipment & -0.199 & $80 \%$ & -0.051 & $73 \%$ & 0.446 & 96 \\
\hline & $\begin{array}{l}\text { - Manufacture of electronic components, computer; } \\
\text { visual, sounding and communication equipment }\end{array}$ & -0.319 & $43 \%$ & -0.115 & $23 \%$ & 0.248 & 247 \\
\hline & $\begin{array}{l}\text { - Manufacture of chemicals and chemical products; } \\
\text { except pharmaceuticals and medicinal chemicals }\end{array}$ & -0.214 & $65 \%$ & -0.019 & $92 \%$ & 0.325 & 197 \\
\hline & - Manufacture of other machinery and equipment & -0.257 & $67 \%$ & -0.115 & $61 \%$ & 0.320 & 207 \\
\hline & $\begin{array}{l}\text { - Manufacture of coke, briquettes and refined } \\
\text { petroleum products }\end{array}$ & -0.203 & $70 \%$ & 0.061 & $135 \%$ & 0.632 & 8 \\
\hline & - Manufacture of basic metals & -0.188 & $78 \%$ & -0.043 & $81 \%$ & 0.317 & 177 \\
\hline & $\begin{array}{l}\text { - Manufacture of wood and of products of wood and } \\
\text { cork; except furniture }\end{array}$ & -0.108 & $53 \%$ & -0.037 & $121 \%$ & 0.459 & 3 \\
\hline & - Manufacture of leather, luggage & -0.324 & $52 \%$ & 0.005 & $-92 \%$ & 0.483 & 11 \\
\hline & - Manufacture of textiles, except apparel & -0.426 & $75 \%$ & -0.145 & $76 \%$ & 0.398 & 12 \\
\hline & - Other manufacturing & -0.125 & $-236 \%$ & -0.010 & $-123 \%$ & 0.653 & 14 \\
\hline & $\begin{array}{l}\text { - Manufacture of medical, precision and optical } \\
\text { instruments, watches and clocks }\end{array}$ & -0.281 & $-77 \%$ & -0.105 & $-88 \%$ & 0.274 & 54 \\
\hline & $\begin{array}{l}\text { Manufacture of wearing apparel, clothing } \\
\text { accessories and fur articles }\end{array}$ & -0.243 & $16 \%$ & -0.132 & $55 \%$ & 0.284 & 60 \\
\hline & - Manufacture of tobacco products & -0.210 & $75 \%$ & 0.018 & $-68 \%$ & 0.292 & 2 \\
\hline & $\begin{array}{l}\text { - Manufacture of pharmaceuticals, medicinal chemical } \\
\text { and botanical products }\end{array}$ & 0.070 & $107 \%$ & -0.034 & $72 \%$ & 0.236 & 91 \\
\hline \multirow{3}{*}{$\begin{array}{l}\text { Wholesale and } \\
\text { Retail trade }\end{array}$} & - Retail trade, except motor vehicles and motorcycles & -0.230 & $-147 \%$ & -0.086 & $77 \%$ & 2.531 & 47 \\
\hline & - Sale of motor vehicles and parts & -0.187 & $77 \%$ & -0.121 & $67 \%$ & 3.622 & 15 \\
\hline & $\begin{array}{l}\text { - Wholesale trade on own account or on a fee or } \\
\text { contract basis }\end{array}$ & -0.160 & $77 \%$ & -0.070 & $16 \%$ & 0.554 & 310 \\
\hline
\end{tabular}

* Based on the median value

Figure 5. Comparison of resiliency among manufacturing industry division

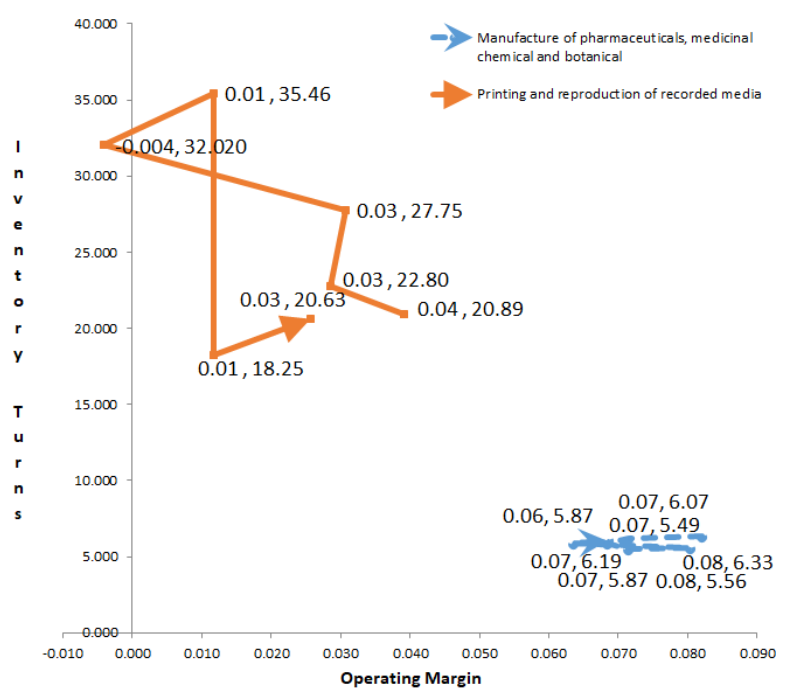

Figure 6. Comparison of resiliency among wholesale and retail trade industry division

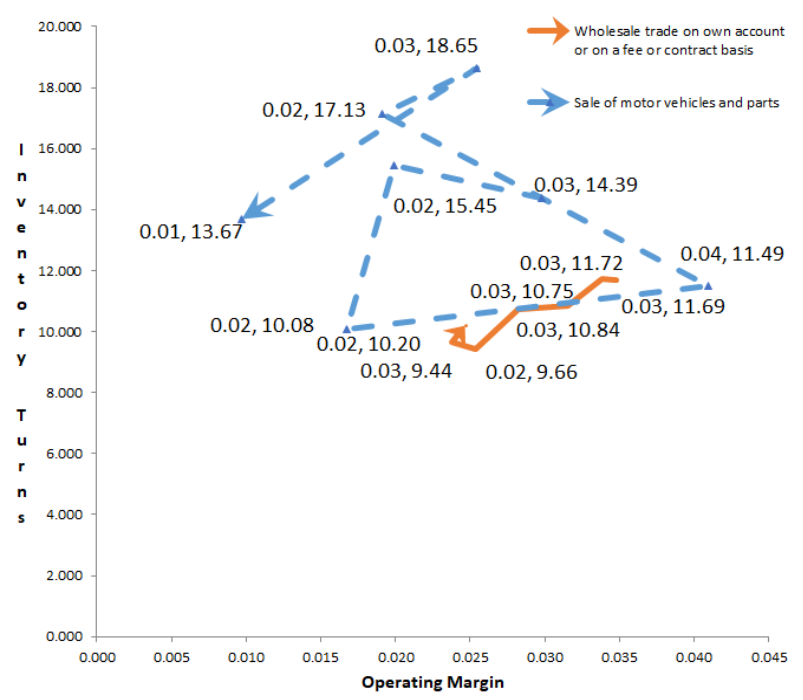




\section{Implications and conclusions}

This study reviewed SCI as a new methodology to measure performance management, as well as applied $\mathrm{C} 2 \mathrm{C}$ to a case study of Korean firms, to compare and present differences for further complementary application. First of all, the C2C for the manufacturing industry increased from 2012-2016. This is particularly true for SMEs, in which the C2C gap increased between SMEs and large enterprises. SCI analysis results show negative values throughout the study period, implying low financial performance in general. Enterprises need to improve the overall soundness of the supply chain through enhancing performance, strengthening cooperation between large and small-and-medium enterprises, and governmental support. Second, since there is no production process included in the wholesale and retail trade industry, it is expected that their $\mathrm{C} 2 \mathrm{C}$ would be shorter than that of the manufacturing industry as the analysis results show. However, from 2012-2016, the C2C of both large enterprises and SMEs have increased continuously. Regarding the SCI analysis results, performance is low, regardless of enterprise size. In particular, performance is worse for large wholesale and retail trade enterprises, as larger enterprises show more fluctuation in resiliency, while SMEs are not stable in the manufacturing industry. More fluctuation in resiliency implies more vulnerability to business environment changes, such as stagnant domestic demand. Therefore, it is necessary to increase inventory management efficiency in order to increase resiliency in the case of prolonged domestic stagnation. Third, according to the analysis results for both industries, $\mathrm{C} 2 \mathrm{C}$ and SCI analysis results were in disagreement. The gap between $\mathrm{C} 2 \mathrm{C}$ and SCI analysis results varies by industry and we assume features of each industry affect the results. For instance, the $\mathrm{C} 2 \mathrm{C}$ of the manufacture of pharmaceuticals, medicinal chemical and botanical products is the longest, implying low performance, while this sector exhibits a good score in the $\mathrm{SCI}$ analysis results. Our assumption is that this industry sector experienced financial hardship during the study period as it has a long $\mathrm{C} 2 \mathrm{C}$ but it was robust under circumstantial changes over time as its resiliency value is low. This addresses the necessity of using both $\mathrm{C} 2 \mathrm{C}$ and SCI as complementary measurements. Lastly, it cannot be denied that $\mathrm{C} 2 \mathrm{C}$ and $\mathrm{SCI}$ which have been compared in this study have limitations in supply chain performance evaluation because they are both based on annual reports. Supply Chain LCC includes qualitative aspects through expert opinions with other quantitative components in the SCI. Inclusion of non-financial indicators, such as customer service, and balance between financial and non-financial indicators should be considered in future studies.

Our analysis considers Korean manufacturing and wholesale and retail firms, as they are representative industry sectors in Korea. In the further studies, we will expand our scope to include service and healthcare industries.

\section{Acknowledgement}

This work was supported by Jungseok Research Institute of International Logistics and Trade Research Grant (INHAJRI-2017).

\section{References}

Abuzayed, B., 2012. Working capital management and firms' performance in emerging markets: The case of Jordan. International Journal of Managerial Finance 8, 155-179.

Capkun, V., Hameri, A., Weiss, L.A., 2009. On the relationship between inventory and financial performance in manufacturing enterprises, International Journal of Operations \& Production Management 29, 789-806.

Cecerre, L., Mayer, A., 2014a. The supply chain index : Improving strength, balance and resiliency. Supply Chain Insights LLC. Available at http://supplychaininsights.com/wp-content/uploads/2014/05/The_Supply_Chain_Index-Improving_Strength_Balan ce_and_Resiliency-12_MAY_2014.pdf.

Cecerre, L., Mayer, A., 2014b. Supply chain index: Evaluating the consumer value network. Supply Chain Insights LLC. Available at https://www.slideshare.net/loracecere/the-supply-chain-index-evaluating-the-industrial-value-network-18-aug-2014.

Cecerre, L, Hart, H., Denman, R., Borthwick, S., 2017. 2017 Supply chains to admire : A seven-year view of progress on supply chain excellence. Supply Chain Insights LLC. Available at http://beetfusion.com/sites/default/files/2017_Supply_Chains_to_Admire13_JUN_2017-FINAL.pdf.

Chen, H., Frank, M.Z., Wu, O.Q., 2005. What actually happened to the inventories of American enterprises between 1981 and 2000 ? Management Science 51, 1015-1031

Christopher, M., Gattorna, J., 2005. Supply chain cost management and value based pricing. Industrial Marketing Management 34, 115-121.

Darush, Y., Peter, Ö., 2014. The impact of cash conversion cycle on firm profitability: An empirical study based on Swedish data. International Journal of Managerial Finance 10, 442-452.

Deloof, M., 2003. Does working capital management affect profitability of Belgian firms?. Journal of Business Finance \& Accounting 30, 573-588.

Eljelly, A., 2004. Liquidity-profitability tradeoff: An empirical investigation in an emerging market. International Journal of Commerce \& Management $14,48-61$.

Farris, I.M, Hutchison, P.D., Hasty R.W., 2005. Using cash-to-cash to benchmark: Service industry performance. The Journal of Applied Business Research 21, 113-124.

Kim, D.K., Kwon, O.K., Bail, I.S., 2003. An empirical study on the supply chain asset performance of Korean companies. IE Interfaces 


\section{$16,167-173$.}

Jahng, G.J., Woo, Y.S., 2011. The relationship between supply chain management performance metrics and corporate value for firms in Korea by using multiple linear regression analysis : Focused on inventory and cash-to-cash cycle time. Korean Journal of Logistics 19, 87-110.

Jahng, G.J., Woo, Y.S., 2012. The study on the inventory as performance measures in supply chain management and financial performance. Korean Journal of Business Administration 25, 2629-2664.

Garcia, T.J., Martinez, S.P., 2007. Effects of working capital management on SME profitability. International Journal of Managerial Finance 3, 164-177.

Gill, A., Biger, N., Mathur, N., 2010. The relationship between working capital management and profitability: Evidence from the United States. Business and Economics Journal 10, 1-9.

Jay, J.E., Alec, C.J., 2011. Cash conversion cycle management in small firms: Relationships with liquidity, invested capital, and firm performance. Journal of Small Business \& Entrepreneurship 24, 381-396.

Jose, M., Lancaster, C., Stevens, J.L., 1996. Corporate returns and cash conversion cycles. Journal of Economics and Finance 20, $33-$ 46.

Lazaridis, L., Tryfonidis, D., 2006. The relationship between working capital management and profitability of listed enterprises in the Athen stock exchange. Journal of Financial Management and Analysis 19, 1-12.

Lyroudi, K., Lazaridis, Y., 2000. The cash conversion cycle and liquidity analysis of the food industry in Greece. EFMA 2000 Athens. Available at SSRN: https://ssrn.com/abstract=236175 or http://dx.doi.org/10.2139/ssrn.236175.

Mucettola, M., 2014. Cash conversion cycle and firm's profitability: An empirical analysis on a sample of 4,226 manufacturing SMEs of Italy. International Journal of Business and Management 9, 25-35.

Panigrahi, A., 2013. Cash conversion cycle and firms' profitability - A study of cement manufacturing companies of India. International Journal of Current Research 5, 1484-1488.

Richards, V.D., Laughlin, E.J., 1980. A cash conversion cycle approach to liquidity analysis. Financial Management 9, 32-38.

Sharma, A.K., Kumar, S., 2011. Effect of working capital management on firm profitability: Empirical evidence from India. Global Business Review 12, 159-173.

Swamidass, P.M., 2007. The effect of TPS on US manufacturing during 1981-1998: Inventory increased or decreased as a function of plant performance. International Journal of Production Research 45, 3763-3778.

Uyar, A., 2009. The relationship of cash conversion cycle with enterprise size and profitability: An empirical investigation in Turkey. International Research Journal of Finance and Economics 24, 186-193. 